\title{
ANALYSIS OF THE EFFECT OF PROFITABILITY, LIQUIDITY, LEVERAGE AND COMPANY GROWTH AGAINST DIVIDEND POLICY IN LQ-45 COMPANIES PERIOD 2015-2017
}

\author{
Wisnu Adityo; Mohamad Heykal \\ Accounting Department, Faculty of Economics and Communication, Universitas Bina Nusantara \\ Jl. K.H. Syahdan No. 9, Kemanggisan, Jakarta, 021 - 534 5830, Indonesia \\ 1wisnu.adityo@binus.ac.id; ${ }^{2}$ mheykal@binus.edu
}

Received: $12^{\text {th }}$ September 2019 / Revised: $6^{\text {th }}$ December $2019 /$ Accepted: $20^{\text {th }}$ March 2020

\begin{abstract}
This study is conducted to determine the effect of profitability, liquidity, leverage, and the growth of the company on dividend policy in the LQ-45 company listed on the Indonesia Stock Exchange for the period 2015-2017. This type of research is quantitative. Data analyzed is in a total of 81 observations. This study used Eviews version 9 for data analyzing. Results indicate that profitability has a significant negative effect on dividend policy while liquidity, leverage, and growth have no significant effect on dividend policy.
\end{abstract}

Keywords: profitability, liquidity, leverage, growth, dividend policy

\section{INTRODUCTION}

The capital market plays an important role in encouraging companies to go public to further improve their performance by announcing earnings and dividends distributed to the shareholders of the company. LQ-45 companies are the most liquid company on the Indonesian Stock Exchange. Companies with category LQ-45 are companies that have high market capitalization and liquidity. LQ-45 can be a benchmark for investors in measuring the dividend policy of other companies.

The goal of a company is achieving maximum profit. To meet its goal, a company needs a variety of assets (machinery, land, buildings, supplies of raw materials and so forth) to run its operations. To finance those assets, a company requires sources of funds. The sources of funds should be managed carefully so the operations run smoothly. How to use and allocate the sources of funds is called financial management. Financial management within a company or organization involves planning, analysis and financial control. Those who carry out these activities are called financial managers. Financial activities undertaken by the finance manager is divided into two main activities, obtaining funds and allocating these funds in various forms of investment financing and spending efficiently. Therefore, financial managers need to take three important decisions, those are investment, funding, and dividends decisions (Riyanto, 2013: 3).

Dividend policy can not be separated from funding decisions. Dividend policy is a policy to determine how much profits should be returned to the shareholders and how much 
should be reinvested. The dividend policy in this study is measured using the Dividend Payout Ratio (DPR). A company decides to share profits as dividends, will reduce the amount of retained earnings which ultimately reduces the source of funds that will be used to develop the company. Conversely, if a company does not share its profits as a dividend then it will have an impact on investors since dividends are one of the advantages that make investors want to invest their money into the company (Hery, 2016).

There are many obstacles the company has that can make it is not able to pay dividends to its shareholders. The inability to pay dividends will impact the decline in the percentage of DPR. For example, a phenomenon that occurred in PT Indofood Sukses Makmur Tbk. It distributed dividends from the financial year 2015 amounting to Rp 168 per share, or equivalent to Rp1.47 trillion. This number was a decline from the 2014 fiscal year dividends of Rp220 per share. This is because Indofood had a decline in net profit in 2015 by by 24.7 percent to IDR 2.97 trillion from the achievements of 2014 at Rp3,95 trillion.

Dividend policies often lead to conflicts of interest between company management and shareholders. Dividend policy is a difficult decision for the management company because the distribution of dividends, on the one hand, will meet investor expectations to get a return as a profit from the investment made, while on the other hand, a company with dividends distribution is expected to maintain the survival of the company. The company management needs to determine an optimal dividend policy that can be a fair policy between meeting shareholders' expectations and the company's growth. Shareholders have a goal in investing their funds, which is to obtain income that can be in the form of dividend income or capital gains. Revenue is not based on the company's internal management policy but is based on the results or performance achieved by the company that is reflected in the published financial statements. Investors who are not willing to take high risks will choose dividends over capital gains in the future and are only oriented toward dividends at this time. Investors generally want a stable dividend distribution. The distribution of relatively stable dividends will increase investor confidence in the company because it will reduce investor uncertainty (Sandy and Joy, 2013).

In this study, a sample is selected from companies included in the LQ-45 index listed on the Indonesia Stock Exchange. The LQ-45 group stock index is one of the best stock indexes and has good company performance. Companies included in the LQ-45 index are companies that have good financial performance and good financial management, while at the same time paying attention to the welfare of their shareholders in addition to the interests of the company.

Prior literature found mixed results on the factors that influence dividend policy. This reason motivates this study to explore the determinants of the level of dividend policy in LQ-45 companies from 2015-2017.

Because of that there are some hypotheses that we will make.

Based on the signaling hypothesis theory, companies that have high profitability have a tendency to distribute higher dividends This is because companies that have high profitability will provide positive signals to investors. High profitability indicates that the company is in good condition, so that through its financial statements investors will invest funds or capital into the company. With the increase in funds obtained by these investors will make the company's funding higher. This will make the company able to fulfill its obligations in dividend distribution. Thus, the higher the level of profitability of the company, the opportunity for companies to distribute dividends is higher. This is in line with research conducted by Mirza and Javed (2013). The study found that profitability has an influence on dividend policy Otherwise, Sunarya (2013) states that liquidity is the company's ability to meet short-term obligations. A high level of liquidity means that the company has good performance, indicating the company's ability to meet its short-term obligations, including paying dividends. And also Companies with high levels of debt will try to reduce the agency cost of debt by reducing debt, so that to finance the investment used funding from internal cash flow. Shareholders will give up internal cash flow which previously could be used to pay dividends to finance investment 
Therefore, the research problem can be formulated as follows:

a. Does Return on Assets (ROA) affect the Dividend Payout Ratio (DPR) in the LQ-45 company listed in Indonesia Stock Exchange (BEI) in 2015-2017?

b. Does the Current Ratio (CR) affect the Dividend Payout Ratio (DPR) in the LQ-45 company listed in Indonesia Stock Exchange (BEI) in 2015-2017?

c. Does the Debt to Equity Ratio (DER) affect the Dividend Payout Ratio (DPR) in the LQ-45 company listed in Indonesia Stock Exchange (BEI) in 2015-2017?

d. Does the Growth affect Dividend Payout Ratio (DPR) in the LQ-45 company listed in Indonesia Stock Exchange (BEI) in 2015-2017?

\section{METHODS}

All the financial data used in this research is secondary data taken from the official website of the Indonesia Stock Exchange, in the form of annual financial reports of the company over the period of 2015-2017. Other supporting data sources in the form of references or literature from various books or media, through websites, scientific journals and other sources related to this research.

Sample selection is done by a purposive sampling method and 27 companies of LQ-45 are selected based on the criteria specified. Five banking companies, 10 companies that are not consistently listed over the period of the sample, and 3 companies that do not use the Rupiah in their financial statements are dropped from the sample.

The hypothesis that will be tested in this research is related to the presence or absence of significant effect from the independent variables (Return on Assets, Current Ratio, Debt to Equity Ratio, and Assets Growth) to the dependent variable (Dividend Payout Ratio), using the multiple linear regression analysis method. Previously, classical assumption testing was done. Before testing the classical assumptions, the collected data was detected by existing outliers. Data processing techniques performed using Microsoft Excel and E-Views version 9.

\section{RESULTS AND DISCUSSION}

The results of the Return On Assets effect which shows the value of $t$ statistics with a negative direction of 3.617246 and the probability value $<0.05(0.0008<0.05)$ then $\mathrm{H}_{0}$ is rejected $\mathrm{H}_{1}$ is accepted, which means Return on Assets has a negative effect on dividend policy. This indicates that profitability affects dividend policy. if company's retained earnings increased the probability of the dividend policy will decrease.

Profitability is the company's ability to earn profits in relation to sales, total assets, and own capital. Thus, long-term investors will be very interested in this analysis. Dividend policy is a decision whether profits obtained by companies at the end of the year will be distributed to shareholders in the form of dividends or will be retained to increase capital for investment financing in the future. Dividends can only be distributed if it has been attentive to the needs of funds including investment was profitable. Dividend policy determines the placement of company profits, between paying to shareholders and reinvesting into a company. The profits generated by a company are usually often uncertain, therefore managers will maintain the level of dividend payments if in the future it turns out that the net profit generated by a company tends to deteriorate. If the company has a large profit, the company will allocate the profit to retained earnings for the company's operations or finance investment so that it will reduce the distribution of dividends.

The results of the research are similar to Pradana and Sanjaya (2014) and Anisah (2014). The results of the Return on Asset research affect the dividend policy. The results of this research are not the same with Fathonah and Amanah (2016) that ROA has no effect on dividend policy.

The results of the effect of Current Ratio which indicate the value of the $t$ statistic with positive direction and value of 0.529640 probability > $0.05(0.5990>0.05)$ then $\mathrm{H}_{0}$ accepted $\mathrm{H}_{2}$ rejected, which means current ratio has no positive effect on dividend policy. The results of this research indicate that the ability of companies to pay short debts has no effect on dividend policy.

It is suspected that current ratio is also better to reflect the company's ability to pay short-term debt (current liabilities) so it is not 
an important consideration in dividend policy. Besides, the high current debt will result in operational activities of the company are widely used to pay off debts to third parties, as a result, reduces the ability Integration net profit optimal impact on dividend payments. Liquidity is one of the factors that affect dividend policy, but that does not mean the seamless payment of debt can conclude that the company will pay dividends. Investors see the size of the dividends received from the value of profits and the market price of shares that can be generated by the company in one year.

This research is similar to the results of the research of Huda and Abdullah (2013) that the Current Ratio has no effect on dividend policy. Different from the results of the research by Idawati and Sudiartha (2012) that $\mathrm{CR}$ affects dividend policy.

The results of the effect of Debt To which shows the value of $t$ statistic with positive direction and value of 1.123285 probability $<0.05(0.2674>0.05)$ then $\mathrm{H}_{0}$ accepted $\mathrm{H}_{3}$ rejected, which means Debt to Equity does not affect positively on dividend policy. The results of this research indicate that the ability of companies to pay long debts has no effect on dividend policy.

The more debt to be paid, the greater the funding should be provided so that it will reduce the amount of the dividend to be paid to the shareholders. One of the factors that affect the dividend policy is the supervision of the companies where sometimes the owners do not want to lose control of the company. If the company se eks funds from its own capital, it is likely to enter new investors, and this will certainly reduce the power of the old owners in controlling the company. Therefore, companies tend not to distribute dividends so that control remains in the hands of the old owner.

This research is similar to the results of the research of Lestari (2017) research results Debt To Equity Ratio does not affect the dividend policy. This research is not the same as Sprott (2018) DER research results affect the dividend policy.

The results of the Asset Growth effect show the value of $t$ statistic with negative direction of 1.497157 and probability values> $0.05(0.1415>0.05)$ then $\mathrm{H}_{0}$ is accepted $\mathrm{H}_{4}$ rejected, which means Asset Growth does not negatively affect dividend policy. The results of this research indicate that company growth has no effect on dividend policy.

One of the company's growth can be assessed through the growth of assets owned. Based on the results of the research, it was found that even though the company was experiencing growth, managers tend to continue to distribute dividends stably. The growing need for funds due to needs related to the growth and payment of dividends to shareholders causes the company to use external sources of funds. This is indicated by the increase in the level of debt of the sample companies during the research period. Based on the signaling theory, the distribution of dividends is still done because managers want to give a positive signal about the good future of the company. Thus, it is expected that potential investors will be interested in investing their shares in the company concerned so that it can gradually reduce the company's dependence on the use of external funding sources.

This research is consistent with the results of the research of Alfina and Nur (2015) that Growth Asset has no effect on dividend policy. Different from the research of Liana, et al (2013) that the results of AG's research affect dividend policy.

\section{CONCLUSION}

Based on the analysis and testing of data that has been carried out by researchers in chapter 4, it can be concluded that:

1. Profitability has a negative effect on dividend policy on LQ-45 companies listed on the Indonesia Stock Exchange in 2015-2017.

2. Liquidity has no effect on dividend policy on LQ-45 companies listed on the Indonesia Stock Exchange in 20152017.

3. Leverage has no effect on dividend policy on LQ-45 companies listed on the Indonesia Stock Exchange in 20152017.

4. The company's growth has no effect on dividend policy on LQ-45 companies listed on the Indonesia Stock Exchange in 2015-2017. 
Based on research that has been done, as for the suggestion that the author wants to give is as follows:

1. For further research, researchers can add other variables that affect dividends on the company, extend the observation period and increase the research sample.

2. For the company, in addition to paying attention to profitability, liquidity, leverage, and company growth to improve dividend policy, it is also necessary to consider other factors that can show the condition of the company more broadly in deciding dividend policy.

3. For investors, it is expected to be more observant in assessing the condition of the company by looking at the factors that affect increase in the dividend policy.

\section{REFERENCES}

Alfina, Febrisa dan Nur, Fadjrih. 2015. Pengaruh Profitabilitas, Cash Position, Leverage, dan Growth terhadap Kebijakan Dividen. Jurnal Ilmu \& Riset Akuntansi: Vol.4, No.3, hal 1-15.

Anisah. 2014. Pengaruh Profitabilitas, Cash Position, Leverage, Growth Terhadap Kebijakan Pembagian Dividen. Jurnal Akuntansi: Volume 3 No 6. Sekolah Tinggi Ilmu Ekonomi Indonesia (STIESIA) Surabaya.

Fathonah, N. and Amanah, L. 2016. Pengaruh Free Cash Flow, Profitabilitas dan Debt to Equity Terhadap Rasio Dividen. Jurnal Ilmu dan Riset Akuntansi: vol. 5, no. 10.

Hery. 2016. Akuntansi: Aktiva, Utang, dan Modal. Yogyakarta: Gava Media.

Huda, Nusrat dan Abdullah, Mohammad Nayeem. 2014. Relationship between Ownership Structure and Dividend Policy: Empirical Evidence from 78 Chittagong Stock Exchange. World
Review of Business Research, 4(3), pp: 14-34.

Idawati, Ida Ayu Agung dan Sudiartha, Gede Merta. 2012. Pengaruh Profitabilitas, Likuiditas, Ukuran Perusahaan Terhadap Kebijakan Dividen Perusahaan Manufaktur di BEI. Jurnal Ekonomi \& Bisnis: Volume 3. No 6.

Lestari, D. 2017. Profitability, Growth Opportunities, Leverage, Ukuran Perusahaan, dan Kebijakan Dividen. Jurnal Riset Manajemen Dan Bisnis (Jrmb) Fakultas Ekonomi Uniat, 2 (September), 227-240.

Liana, S., Merry, S., Sufiyati \& Sriwahyuni. 2015. Pengaruh Liquidity, Profitability, Size, Collateral Assets, Growth, dan Institutional Ownership Terhadap Dividend Policy Perusahaan Manufaktur yang Terdaftar di BEI. Jurnal Akuntansi: Vol.18, No.1, hal 149-162.

Pradana, Salvatore Wika Lingga dan Sanjaya, I Putu Sugiartha. 2014. Pengaruh Profitabilitas, Free Cash Flow, dan Investment Opportunity Set Terhadap Dividend Payout Ratio (Studi Empiris Pada Perusahaan Perbankan Yang Terdaftar Di BEI). Jurnal SNA 17 Mataram Universitas Atma Jaya Yogyakarta.

Riyanto, Bambang. 2013. Dasar-Dasar Pembelanjaan Perusahaan. Edisi 4. Yogyakarta: BPFE.

Sandy, Ahmad dan Asyik, Nur Fadjrih. 2013. Pengaruh Profitabilitas Dan Likuiditas Terhadap Kebijakan Dividen Kas Pada Perusahaan Otomotif. Jurnal Ilmu dan Riset Akuntansi. 1(1): 58-76.

Sunarya, Devi Hoei. 2013. Pengaruh Kebijakan Utang, Profitabilitas dan Likuiditas Terhadap Kebijakan Dividen Dengan Size Sebagai Variabel Moderasi Pada Sektor Manufaktur Periode 20082011. Jurnal Ilmiah Mahasiswa Universitas Surabaya 2(1): 1-19. 
Table 1. Descriptive Statistics

\begin{tabular}{llllll} 
& Y_DPR & X1_ROA & X2_CR & X3_DER & X4_AG \\
\hline \hline Mean & 0.599803 & 0.301736 & 1.379723 & 1.018096 & 0.353517 \\
Median & 0.614568 & 0.279918 & 1.252099 & 0.933622 & 0.316953 \\
Maximum & 1.088583 & 0.676672 & 2.725997 & 1.956222 & 0.765634 \\
Minimum & 0.193488 & 0.122862 & 0.693940 & 0.391771 & 0.147932 \\
Std. Dev. & 0.207094 & 0.134086 & 0.434808 & 0.386665 & 0.140950 \\
Skewness & 0.191891 & 1.268826 & 1.166363 & 0.490324 & 0.899410 \\
Kurtosis & 2.375204 & 4.107370 & 3.973748 & 2.369153 & 3.236389 \\
Jarque-Bera & 1.680183 & 23.95609 & 19.96810 & 4.248864 & 10.28636 \\
Probability & 0.431671 & 0.000006 & 0.000046 & 0.119501 & 0.005839 \\
Sum & 44.98522 & 22.63017 & 103.4792 & 76.35717 & 26.51381 \\
Sum Sq. Dev. & 3.173697 & 1.330444 & 13.99031 & 11.06374 & 1.470146 \\
Observations & 75 & 75 & 75 & 75 & 75
\end{tabular}

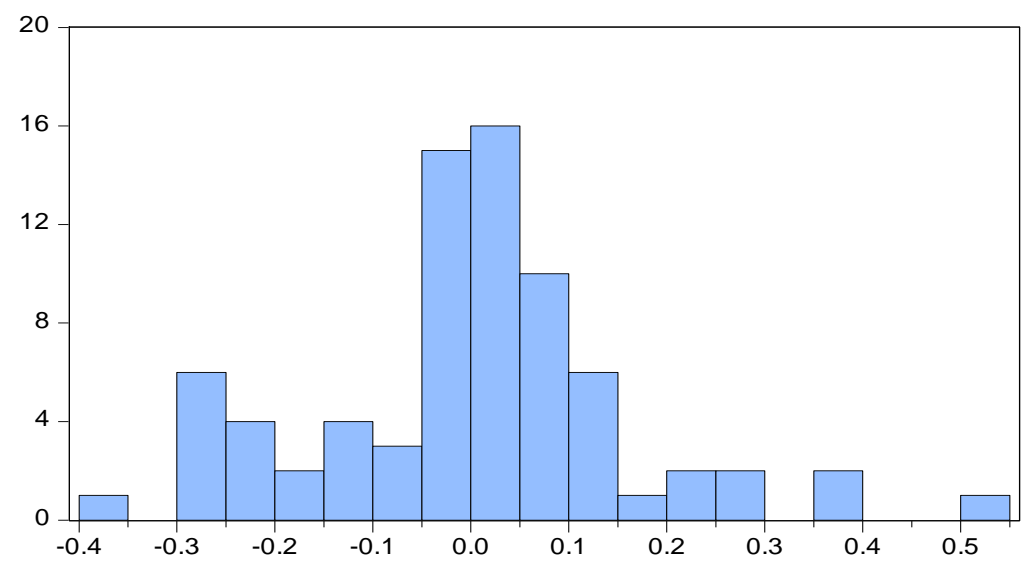

\begin{tabular}{|lr|}
\hline \multicolumn{2}{|l|}{ Series: Residuals } \\
Sample 1 81 \\
Observations 75 \\
Mean & $3.77 e-17$ \\
Median & 0.007919 \\
Maximum & 0.526077 \\
Minimum & -0.374875 \\
Std. Dev. & 0.159430 \\
Skewness & 0.257696 \\
Kurtosis & 4.133760 \\
& \\
Jarque-Bera & 4.847002 \\
Probability & 0.088611 \\
\hline
\end{tabular}

Table 2 Regression Result Table

Variable Coefficient Std. Error t-Statistic Prob.

\begin{tabular}{lllll}
\hline \hline C & 1.009480 & 0.263150 & 3.836144 & 0.0004 \\
X1_ROA & -1.813429 & 0.501329 & -3.617246 & 0.0008 \\
X2_CR & 0.048727 & 0.092001 & 0.529640 & 0.5990 \\
X3_DER & 0.164014 & 0.146013 & 1.123285 & 0.2674 \\
X4_AG & -0.273574 & 0.182729 & -1.497157 & 0.1415 \\
\hline \hline
\end{tabular}

Effects Specification 
Cross-section fixed (dummy variables)

\begin{tabular}{llll}
\hline \hline R-squared & 0.811584 & Mean dependent var & 0.599803 \\
Adjusted R-squared & 0.683119 & S.D. dependent var & 0.207094 \\
S.E. of regression & 0.116578 & Akaike info criterion & -1.167153 \\
Sum squared resid & 0.597974 & Schwarz criterion & -0.209258 \\
Log likelihood & 74.76823 & Hannan-Quinn criter. & -0.784676 \\
F-statistic & 6.317547 & Durbin-Watson stat & 2.665610 \\
Prob(F-statistic) & 0.000000 & & \\
\hline \hline
\end{tabular}


